\title{
RESEARCH NOTE \\ Decrease of flavonol synthase enzymatic activity in Ugni molinae Turcz due to the domestication process
}

\author{
Manuel Chacón-Fuentes ${ }^{1,2}$, Ana Mutis ${ }^{1,2}$, Leonardo Bardehle ${ }^{1,2,3}$, Ivette \\ Seguel $^{4}$, Alejandro Urzúa ${ }^{5}$, and Andrés Quiroz ${ }^{2,3}$ \\ 'Universidad de La Frontera, Facultad de Ingeniería y Ciencias, Departamento de Ciencias Químicas y Recursos \\ Naturales, Laboratorio de Química Ecológica. Av. Francisco Salazar 01145, Casilla 54-D, Temuco, Chile. \\ ${ }^{2}$ Universidad de La Frontera, Centro de Investigación Biotecnológica Aplicada al Medio Ambiente \\ (CIBAMA). Av. Francisco Salazar 01145, Casilla 54-D, Temuco, Chile. \\ ${ }^{3}$ Universidad de La Frontera, Centro de Fruticultura, Facultad de Ciencias Agropecuarias y Forestales. \\ Casilla 54-D, Temuco, Chile. \\ ${ }^{4}$ Instituto de Investigaciones Agropecuarias, Centro Regional de Investigación Carillanca. Temuco, Chile. \\ ${ }^{5}$ Universidad de Santiago de Chile, Facultad de Química y Biología, Departamento de Ciencias del \\ Ambiente, Laboratorio de Química Ecológica. Av. Bernardo O’ Higgins 3363, Santiago, Chile.
}

\begin{abstract}
M. Chacón-Fuentes, A. Mutis, L. Bardehle, I. Seguel, A. Urzúa, and A. Quiroz. 2019. Decrease of flavonol synthase enzymatic activity in Ugni molinae Turcz due to the domestication process. Cien. Inv. Agr. 46(1): 30-39. Flavonoid biosynthesis may be affected by plant domestication, with flavonoid production being reduced in proportion to the degree of domestication. In this context, kaempferol (3,4',5,7-tetrahydroxyflavone) has been identified in the leaves of wild and cultivated Ugni molinae, a berry endemic to Chile. The biosynthetic pathway of kaempferol production begins with naringenin (4',5,7-trihydroxyflavanone), which is converted to dihydrokaempferol (3,4',5,7-tetrahydroxyflavanone), catalyzed by flavanone 3ß-hydroxylase (FHT) and then converted to kaempferol by a bifunctional enzyme called flavonol synthase (FLS). Therefore, our study aims to evaluate how FLS activity is affected in murtilla plants that are subjected to the domestication process. Kaempferol was quantified from methanolic extracts of leaf samples collected from both cultivated and wild U. molinae plants using high-performance liquid chromatography, and enzyme extraction was performed to determine FLS activity. The results showed that kaempferol concentration in wild plants from the Soloyo $\left(0.14 \mu \mathrm{g} \mathrm{g}^{-1}\right)$, Mehuín $\left(0.18 \mu \mathrm{g} \mathrm{g}^{-1}\right)$ and Queule $\left(0.25 \mu \mathrm{g} \mathrm{g}^{-1}\right)$ sampling areas was higher than in their cultivated counterparts. Our data are consistent with the FLS activity detected in samples obtained from Manzanal Alto (134.79 pKatal, Soloyo (96.48 pKatal), and Mehuín (119.97 pKatal). These samples also exhibited higher enzymatic activity than their cultivated counterparts. Together, these data suggest that FLS activity is negatively affected by the domestication process.
\end{abstract}

Key words: Cultivated, enzyme activity, Kaempferol, naringenin, wild.

Received Mar 01, 2018. Accepted Mar 22, 2019.

Corresponding author: andres.quiroz@ufrontera.cl 


\section{Introduction}

The flavonoid family consists of over 8,000 secondary plant metabolites. Flavonoids are characterized by their C6-C3-C6 skeleton (Nguyen et al., 2016) and can be classified into the following eight subgroups according to their oxidation state and substitution pattern of the C-ring structure: flavanones, dihydroflavonols, flavones, flavonols, flavan-3,4-diols, flavan-3-ols, anthocyanidins, and proanthocyanidins (Xu et al., 2012). Additionally, flavonoids can be conjugated to sugar molecules naturally occurring in plant tissues. These compounds have been associated with a broad range of applications, including antioxidants, insect repellent, and even cancer prevention (Ruiz et al., 2010, Vazhappilly et al., 2017). Flavonols are the most abundant group of flavonoids, and several biological properties have been attributed to these compounds, such as regulation of auxin transport, modulation of flower color, protection from UV radiation, prevention against microorganisms and pest invasions, and signaling interactions with insects and microbes (Nenaah 2013, Dixit et al., 2017, León-Chan et al., 2017, Vazhappilly et al., 2017). Flavonols are produced by the desaturation of dihydroflavonols. These compounds are formed from dihydroflavonols (Figure 1) by the introduction of a double bond between $\mathrm{C}-2$ and $\mathrm{C}-3$, which is catalyzed by flavonol synthase (FLS) (Xu et al., 2012). The B-ring of dihydrokaempferol (3,4',5,7-tetrahydroxyflavanone) can be hydroxylated at the $3^{\prime}$ position by flavonoid $3^{\prime}$-hydroxylase $\left(\mathrm{F}^{\prime} \mathrm{H}\right)$ or at the $3^{\prime}$ and $5^{\prime}$ positions by flavonoid $3^{\prime} 5^{\prime}$-hydroxylase $\left(\mathrm{F}^{\prime} 5^{\prime} \mathrm{H}\right)$ to produce dihydroquercetin and dihydromyricetin, respectively. The oxidation reaction introducing the $\mathrm{C}-2 / \mathrm{C}-3$ double bond is considered to be specific for dihydroflavonol substrates (Preub et al., 2009, Lukacin et al., 2000, Li et al., 2013). Furthermore, FLS has been reported as a bifunctional enzyme capable of transforming not only dihydrokaempferol (3,4',5,7-tetrahydroxyflavone) but also naringenin (4',5,7-trihydroxyflavanone) into kaempferol (Lukacin et al., 2003). Regarding pest management, various studies have focused on the deterrent and anti-feeding properties of these compounds. Onyilagha et al. (2012) found that kaempferol, quercetin, and isorhamnetin deterred feeding of the flea beetle, Phyllotreta cruciferae (Coleoptera: Chrysomelidae), on Camelina sativa leaves. Additionally, Selin-Rani et al. (2016) reported that quercetin isolated from Euphorbia hirta L. was toxic to Spodoptera litura Fab. (Lepidoptera: Noctuidae) larvae and showed that 6 ppm caused a $94.6 \%$ mortality rate. Furthermore, larval weight was reduced to $100 \mathrm{mg}$ at the same dose. Finally, Nenaah (2003) reported that a leaf methanolic extract from Calotropis procera that contained kaempferol showed considerable toxicity to Sitophilus oryzae (Coleoptera: Curculionidae) and Rhyzopertha dominica (Coleoptera: Bostrichidae) and that concentrations of $5 \mathrm{~mL}$ $\mathrm{cm}^{-2}$ caused a mortality rate of $86 \%$ in $S$. oryzae with applications of $2 \mathrm{~mL}$ of extract.

During the last 20 years, a highly polymorphic perennial and wild native shrub from Chile, denominated "Murtilla", Ugni molinae (Hoffmann 2005; Valdebenito et al., 2003), has been domesticated and studied by the Institute of Agricultural Research (Instituto de Investigaciones Agropecuarias, INIA), Carillanca, in the Araucanía region of Chile (Chacón-Fuentes et al., 2016). One hundred sites were originally selected in southern Chile for the collection of wild $U$. molinae plants, and cuttings were grown for the first 10 years under shading and then transplanted to the field. There is strong economic interest in the production of $U$. molinae fruit, both globally and regionally, due to its high antioxidant content that is mainly provided by flavonol compounds (Simirgiotis et al., 2009). The main phenolic compounds reported in murtilla plants are myricetin, quercetin, kaempferol and their glycosides compounds (Peña-Cerda et al., 2017). A recent study by Chacón-Fuentes et al. (2015) reported differences in the flavonol concentration present in wild and cultivated plants of $U$. molinae, with domestication decreasing flavonol production in cultivated plants. Nonetheless, information about 


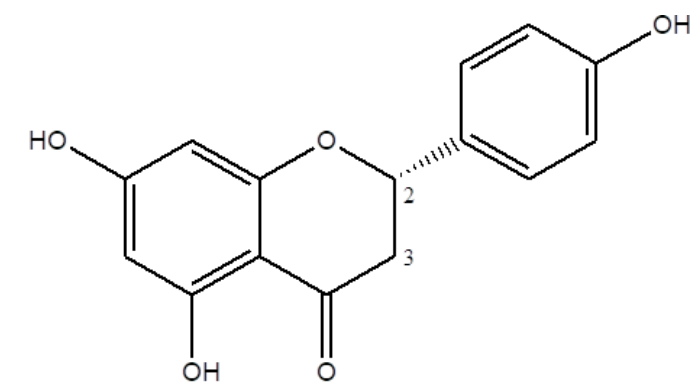

$(2 S)$-Naringenin<smiles>O=C1c2c(O)cc(O)cc2O[C@H](c2ccc(F)cc2)[C@@H]1O</smiles>

(+)-trans-Dihydrokaempferol

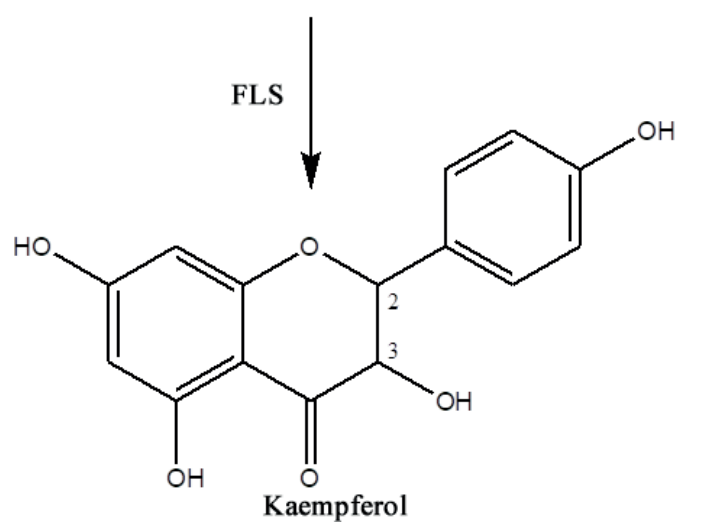

Figure 1. Schematic of the kaempferol biosynthetic pathway from naringenin to kaempferol using flavonol synthase enzyme activity. FLS: flavonol synthase. FHT: flavanone 3ß-hydroxilase.

FLS activity in berries is still limited (Flores et al., 2014) and currently there is no information about flavonol synthase in U. molinae. We hypothesize that there is lesser FLS activity and kaempferol production in leaves of cultivated $U$. molinae plants than in wild $U$. molinae plants. To test this hypothesis, kaempferol concentration in leaves of both wild and cultivated plants was analyzed using naringenin as a substrate for the FLS enzyme.

\section{Material and methods}

\section{Cultivated material collection}

Seven different ecotypes of cultivated plants (Ecotypes: 08-1, 12-1, 14-4, 18-1, 19-1, 22-1, and 23-2) of $U$. molinae were used to obtain cuttings at the Experimental Station-Tranapuente of the Institute of Agricultural Research (Instituto de Investigaciones Agropecuarias, INIA), 
Carillanca, in La Araucanía region of Chile $\left(38^{\circ} 45^{`} \mathrm{~S}, 73^{\circ} 21^{\prime} \mathrm{W}\right)$. A common garden for wild and cultivated plants was established and cuttings were grown under shading (ambient temperature and humidity) in 8-L pots at INIA Tranapuente, a locality near Puerto Saavedra, a coastal zone close to the Pacific Ocean with a moderate oceanic climate (Scheuermann et al., 2008). After 1 year of acclimation in the common garden, leaves were sampled from the four cardinal directions at the same height and stored at $-20{ }^{\circ} \mathrm{C}$ until the kaempferol analysis and enzyme assay were carried out.

\section{Wild material collection}

Wild cuttings were sampled from the original geographical area where their cultivated counterparts were collected approximately 20 years ago. The following areas were used for the cutting collections: Caburgua (39¹1'S, 7149`W), Pucón $\left(39^{\circ} 17^{`} \mathrm{~S}, 71^{\circ} 55^{`} \mathrm{~W}\right)$, Manzanal Alto $\left(38^{\circ} 03^{\prime} \mathrm{S}\right.$, $73^{\circ} 10^{`} \mathrm{~W}$ ), Soloyo (383도, $\left.72^{\circ} 34^{`} \mathrm{~W}\right)$, Porma ( $\left.39^{\circ} 08^{`} \mathrm{~S}, 73^{\circ} 16^{`} \mathrm{~W}\right)$ from La Araucanía, Chile and Mehuín (39 $26^{`}$ S, $\left.73^{\circ} 12^{\prime} \mathrm{W}\right)$, and Queule $\left(39^{\circ} 23^{`} \mathrm{~S}, 73^{\circ} 12^{\prime} \mathrm{W}\right)$ from Los Ríos, Chile. Plants were established in a common garden for 1 year until their use in chemical and enzymatic analyses. Cultivated plants were paired with their respective wild plant counterparts as follows: Eco 08-1/ Caburgua; Eco 12-1/Pucón; Eco 14-4/Manzanal Alto; Eco 18-1/Soloyo; Eco 19-1/Porma; Eco 22-1/ Mehuín; and Eco 23-2/Queule. Cultivated and wild murtilla plants were placed in pots with a substrate composed of sand (25\%) and soil obtained from the same experimental field. Annually, fertilizer consisting of $80 \mathrm{~g}$ of nitrogen (CAN 27), $44 \mathrm{~g}$ of $\mathrm{P}_{2} \mathrm{O}_{5}$ (triple superphosphate) and $43 \mathrm{~g}$ of $\mathrm{K}_{2} \mathrm{O}$ (muriate of potash) was applied to each ecotype and wild plant according to the soil analysis. The fertilizer was applied over 4 periods, coinciding with the budding, flowering, ripening and postharvest plant phenologies (Table 1).

\section{Kaempferol extraction}

Leaves of both cultivated and wild plants were collected from plants located in the common garden. Samples were rapidly frozen in liquid nitrogen for $5 \mathrm{~s}$ (Mikulic-Petkovsek et al., 2012) and then milled in a grinder (1 mm diameter). Milled samples (5 g) were placed in a flask and $25 \mathrm{~mL}$ of chromatographic grade methanol (Sigma-Aldrich, St. Louis, MO) was added $(50 \% \mathrm{v} / \mathrm{v}$ in water, solvent-to-solid ratio of 5:1). Flasks were placed on a magnetic stirrer set at $170 \mathrm{rpm}$ for $20 \mathrm{~min}$ at $30^{\circ} \mathrm{C}$ in the dark. Samples were then filtered through a Whatman $n^{\circ} 1$ filter paper (Whatman International Ltd., Maidstone, U.K.) and the filtrate was lyophilized (Biobase Biodustry BK-FD1CP, Shandong, China). Finally, each sample was suspended in $10 \mathrm{~mL}$ of chromatographic grade methanol and left for 5 min in a Branson 3510 sonicator according to Chacón-Fuentes et al. (2015). Samples were stored at $-20{ }^{\circ} \mathrm{C}$ in amber flasks $(25 \mathrm{~mL})$ until High Performance Liquid Chromatography (HPLC) analyses.

\section{Enzyme extraction}

The $U$. molinae leaves were ground to a fine powder in a mill. The powder (1.5 g), composed of $0.25 \mathrm{~g}$ of quartz sand, $0.25 \mathrm{~g}$ of Polyclar AT, and $4 \mathrm{~mL}$ of $0.1 \mathrm{M}$ Tris $/ \mathrm{HCl}$ (containing $0.4 \% \mathrm{Na}-$

Table 1. Source of fertilizer $\left(\mathrm{g} \mathrm{plant}^{-1}\right)$ applied to murtilla plants during the year according to the plant phenology.

\begin{tabular}{lccccc}
\hline \multirow{2}{*}{ Source } & \multirow{2}{*}{ Annual doses } & \multicolumn{4}{c}{ Application (g plant ${ }^{-1}$ ) } \\
\cline { 3 - 6 } & & Postharvest & Budding & Flowering & Ripening \\
\hline $\mathrm{N}$ & 80 & 20 & 20 & 20 & 20 \\
$\mathrm{P}_{2} \mathrm{O}_{5}$ & 44 & 11 & 11 & 11 & 11 \\
$\mathrm{~K}_{2} \mathrm{O}$ & 42 & 8 & 8 & 8 & 18 \\
\hline
\end{tabular}


ascorbate, $\mathrm{pH}$ 7.25) was completely homogenized (Halbwirth et al. 2009) with a pestle and mortar. The resulting homogenate was then centrifuged (Hitachi, Himac CT15RE) in polypropylene tubes $(2 \mathrm{~mL})$ at $5,000 \mathrm{~g}$ for $10 \mathrm{~min}$ at $4{ }^{\circ} \mathrm{C}$. Finally, the supernatant was collected to perform FLS assays. Preparation was done in triplicate for statistical analysis.

\section{Enzymatic activity}

Flavonol synthase activities in the enzyme extract were measured according to Halbwirth et al. (2009), with slight modifications. Briefly, 20 $\mu \mathrm{L}$ of $50 \mathrm{mM}$ naringenin, $50 \mu \mathrm{L}$ of the enzyme extract obtained above, $5 \mu \mathrm{L}$ of $3.48 \mathrm{mM}$ 2-oxoglutarate, $5 \mu \mathrm{L}$ of $2.01 \mathrm{mM} \mathrm{FeSO}_{4}-7 \mathrm{H}_{2} \mathrm{O}$, and 60 $\mu \mathrm{L}$ of buffer $(0.1 \mathrm{M}$ Tris $/ \mathrm{HCl}+0.4 \% \mathrm{Na}$-ascorbate, $\mathrm{pH}$ 7.25) were mixed. The mixture was incubated (Major Science MD-01N) for $60 \mathrm{~min}$ at $30{ }^{\circ} \mathrm{C}$. The assay was completed by adding $140 \mu \mathrm{L}$ of ethyl acetate, $10 \mu \mathrm{L}$ of acetic acid, and $10 \mu \mathrm{L}$ of $0.1 \mathrm{mM}$ ethylenediaminetetraacetic acid (EDTA). The resulting organic phase was used to perform the HPLC analysis detailed below. Reactions processed without substrates were used as blanks for comparison. Enzyme activity was expressed as pKatal, where one katal is defined as the enzyme activity transforming $1 \mathrm{~mol}$ of compound per s (Flores et al., 2014).

\section{HPLC DAD analysis}

The methanolic extracts obtained from the leaves and enzyme preparations were filtered through a $0.22 \mu \mathrm{m}$ membrane and analyzed by HPLC-DAD. Each sample $(20 \mu \mathrm{L})$ was injected into a Shimadzu autosampler HPLC (SIL-20AHT) equipped with a C-18 column $(250 \times 4.6 \mathrm{~mm}$ I.D.; $5 \mathrm{~mm}$ particle size) maintained at $40^{\circ} \mathrm{C}$ in a column oven (CTO-20A). The analysis was performed using a linear solvent gradient consisting of $1 \%$ formic acid (A) and acetonitrile (B) as follows: 0-5 min,
$5 \% \mathrm{~A} / 95 \% \mathrm{~B} ; 5-10 \min , 30 \% \mathrm{~A} / 70 \% \mathrm{~B} ; 10-20$ $\min , 55 \% \mathrm{~A} / 45 \% \mathrm{~B} ; 20-30 \mathrm{~min}, 5 \% \mathrm{~A} / 95 \% \mathrm{~B}$ at a flow rate of $1 \mathrm{~mL}$ min-1 (Simirgiotis et al., 2009). Kaempferol was monitored at $280 \mathrm{~nm}$. Kaempferol identification was based on comparing the peak retention time in samples to the peak retention time of the kaempferol standard. To construct calibration curves for flavonoids, naringenin and kaempferol standards were dissolved in chromatographic grade methanol (Sigma-Aldrich, St. Louis, MO) at 1,000 $\mathrm{mg} \mathrm{L}^{-1}$. The stock solutions of each standard were used to prepare a serial concentration between 0.05 and $500 \mathrm{mg} \mathrm{L}^{-1}$ (Kumar et al., 2009).

\section{Statistical analysis}

The statistical software Statistix 10 (Tallahassee, Florida, USA) was used to analyze the kaempferol concentration and FLS enzyme activity data. The paired sample $t$-test was used to compare wild and cultivated plants. Data were natural-log transformed to meet the assumptions of normality and homogeneity of variance. Values of $p \leq 0.05$ were considered to be significant. The results are expressed as the means with corresponding standard errors.

\section{Results}

\section{Kaempferol content}

Kaempferol concentration was evaluated for each particular ecotype and compared with the respective wild counterpart. Differences between the ecotypes and their wild counterparts are presented in Figure 2. Significant differences in kaempferol concentrations between cultivated and respective wild counterparts, such as Eco 18-1/Soloyo (0.04 $\mu \mathrm{g} \mathrm{g}^{-1}$ and $\left.0.14 \mu \mathrm{g} \mathrm{g}^{-1}\right),\left(F_{1,5}=61.40 ; p=0.0159\right)$; Eco 22-1/Mehuín $\left(0.03 \mu \mathrm{g} \mathrm{g}^{-1}\right.$ and $\left.0.18 \mu \mathrm{g} \mathrm{g}^{-1}\right),\left(F_{1}\right.$, $\left.{ }_{5}=40.97 ; p=0.0235\right)$ and Eco 23-2/Queule $(0.08 \mu \mathrm{g}$ $\mathrm{g}^{-1}$, and $\left.0.25 \mu \mathrm{g} \mathrm{g}^{-1}\right)\left(F_{1,5}=84.28 ; p=0.0117\right)$ were found using the $t$-tests $(p<0.05)$. 


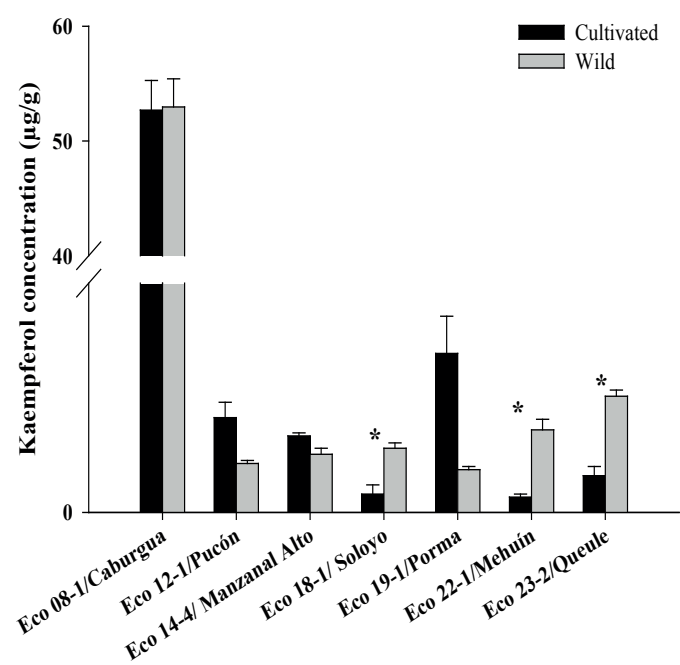

Figure 2. Kaempferol concentration in murtilla plant leaves obtained from all seven cultivated ecotypes and their respective wild counterparts. Bars indicate standard error, and * indicates significant differences between cultivated and wild plants $(p \leq 0.05)$.

\section{Enzymatic activity}

Kinetic studies were carried out to select the best incubation time for the FLS enzymatic assays. Figure 3 shows how the amounts (in nmol) of naringenin consumed, as well as the amount of kaempferol produced, varied over time $(30,60$, 120 , and $240 \mathrm{~min}$ ) at $30^{\circ} \mathrm{C}$ in all cases. The highest level of kaempferol was detected at $60 \mathrm{~min}$ $\left(1.13 \times 10^{6} \mathrm{nmol}\right)$ and coincided with a low level of naringenin $\left(2.79 \times 10^{4} \mathrm{nmol}\right)$. With regards to

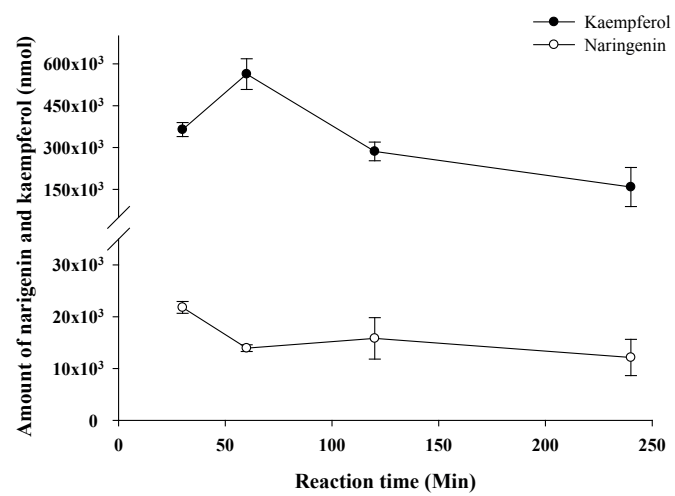

Figure 3. Correlation between the amount of naringenin consumed and kaempferol produced (nmol) during a 240 min reaction time. Data are expressed as the means with corresponding standard errors. the enzymatic activity, significant differences were observed in FLS activity between Eco 14-4 and Manzanal Alto, with 134 pKatal measured in the wild plants and $73 \mathrm{pKatal}$ measured in the cultivated plants $\left(F_{1,5}=7.11 ; p=0.0500\right)$ (Figure $4)$. The highest pKatal values were observed in wild samples collected in Soloyo $\left(F_{1,5}=12.45\right.$; $p=0.0243)$ and Mehuín $\left(F_{1,5}=11.81 ; p=0.0264\right)$, at 96 pKatal and 119 pKatal, respectively. Their cultivated counterparts, Eco 18-1 and Eco 22-1, exhibited significantly lower pKatal values of 66 pKatal and 38 pKatal, respectively (Figure 4). There were no significant differences between cultivated and wild plants $(p>0.05)$ in the other comparisons. Finally, HPLC analysis showed that enzymatic activity only produced kaempferol when the naringenin substrate from murtilla leaves was available; this enzymatic activity was not detected in the blanks.

\section{Discussion}

Plant domestication can affect flavonol biosynthesis, expressed as a decrease in flavonol content, but can increase other productive traits, as part of the so-called domestication syndrome (Meyer et al.,

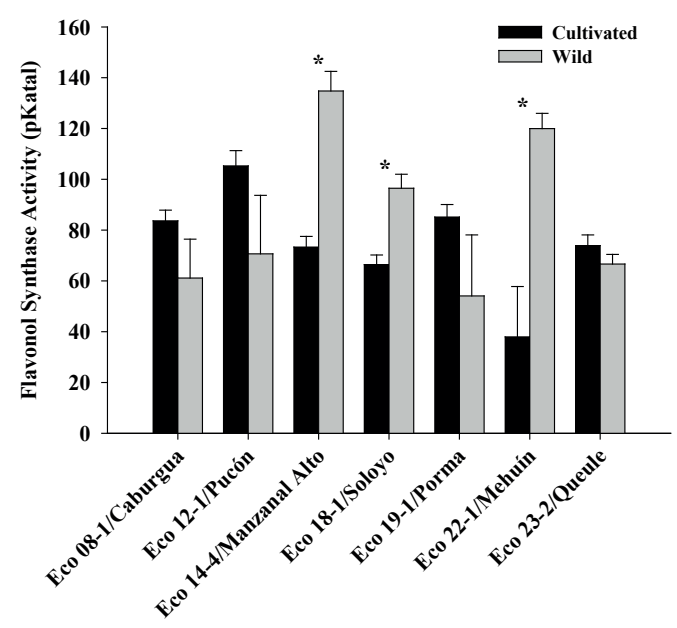

Figure 4. Flavonol synthase activity in murtilla plant leaves from cultivated ecotypes and respective wild counterparts. Bars indicate standard error and * indicates significant differences between cultivated and wild plants $(p \leq 0.05)$. 
2012). However, chemical defenses in plants, such as flavonols, can be affected in unpredictable ways. For example, the compromise between performance and production may be modified at the expense of flavonoid production. Modifications in flavonoid production can be important since flavonoids are responsible for the chemical defense from insect feeding behaviors in plants. Hence, kaempferol could have undergone concentration changes, due to changes in the enzyme flavonol synthase (FLS) pathway (i.e., transforming dihydroflavonol into flavonol or dihydrokaempferol into kaempferol) during the domestication process in murtilla plants, which in turn affected insect feeding behavior. For instance, Fang et al. (2013) observed a positive correlation between kaempferol concentration and FLS enzyme activity in grape berries, Vitis vinifera (cv. Cabernet sauvignon). Flores et al. (2014) also reported a direct correlation between kaempferol concentration and FLS enzymatic activity for strawberry, raspberry, blackberry, redcurrant, and blackcurrant fruits.

Our results showed that changes in kaempferol concentration were directly related to the FLS activity present in murtilla plants. Decreases in kaempferol concentrations of cultivated plants were due to lower enzymatic activity (FLS) compared to wild plants. Specifically, total kaempferol concentration found in plants from wild localities such as Soloyo (La Araucanía region), Mehuín, and Queule (Los Ríos region) were higher than the respective cultivated ecotypes, Eco 18-1, 22-1 and 23-2. These results were consistent with the higher FLS activity shown in Soloyo and Mehuín wild plants than their respective cultivated counterparts (Eco 18-1 and Eco 22-1). Chacón-Fuentes et al. (2017) reported that kaempferol content obtained from the leaves of wild murtilla plants from Mehuín and Queule was higher than in ecotypes 22-1 and 23-2, with concentrations of 0.37 to 0.86 $\mu \mathrm{g} \mathrm{g}^{-1}$ in wild plants and 0.024 to $0.58 \mu \mathrm{g} \mathrm{g}^{-1}$ in cultivated plants. Moreover, when wild and cultivated murtilla plants were compared for kaempferol content a decrease from 1.01 to 0.87 $\mathrm{mg} \mathrm{L}^{-1}$ was reported for the cultivated plants by Chacón-Fuentes et al. (2015). Therefore, plant domestication induced a loss in the defense traits associated with kaempferol concentrations in U. molinae ecotypes Eco 18-1, 22-1 and 23-2. These results suggest that the low FLS activity in cultivated ecotypes can be a consequence of the domestication process. However, information about adaptations under domestication are still scarce (Ross-Ibarra et al., 2007). In our research, we documented changes in FLS activity, which could be caused by environmental (i.e., soil fertilization) or genetic factors (Yang et al., 2008). Murtilla is a novel plant that has been subjected to the domestication process for less than 20 years. The cultivated ecotypes used in this study are clones recently collected from wild locations and thus can be considered in the primary stage of domestication. The significant differences found FLS activity and kaempferol production between wild and cultivated murtilla plants could be based on the strong genetic traits that are retained by plants in wild systems and lost by plants cultivated in agro-ecosystems. Considering that cultivated ecotypes are clones obtained a few years ago from various wild locations (Seguel et al., 2000) it is reasonable to hypothesize that clonal propagation could transfer favorable genotypes, such as FLS activity, to the next generation according to McKey et al. (2009). However, data obtained from Soloyo, Mehuín, and Queule localities showed significant differences between wild plants and their cultivated counterparts indicating adaptation, including adaptations to the kaempferol content, in cultivated plants. Nevertheless, there were no significant differences of kaempferol content and FLS activity among wild and cultivated murtilla corresponding to Caburgua, Pucón, Porma and Eco 18-1, 12-1 and 19-1, respectively. These results would indicate domestication is an ongoing process in which there is a transfer of favorable traits from wild to cultivated ecotypes, specifically in the case of FLS activity and kaempferol production. These findings also suggest that the decrease of both 
kaempferol content and FLS activity could be associated with adaptation processes or somatic mutations in the clonal propagation system. In this context, it is necessary to evaluate the role of fertilization in murtilla plants undergoing the domestication process, as well as the transfer of genetic traits by clonal propagation compared to domesticated plants obtained through sexual propagation (Bautista et al., 2012). Our results showed that the biosynthesis of kaempferol through flavonol synthase activity in murtilla is affected by the domestication process. Wild plants coming from Soloyo, Mehuín, and Queule had significantly higher kaempferol concentration than their cultivated counterparts. Moreover, flavonol synthase activity was significantly higher in Soloyo and Mehuín plants. These results suggest an effect of domestication on the flavonol synthase production which affects kaempferol concentration. Therefore, the plant domestication process, which causes a decrease in the key enzyme flavonol synthase and thereby reduces kaempferol production, has implications for pest insect feeding.

\section{Acknowledgments}

We would like to thank the Graduate Natural Resources Program at the Universidad de La Frontera (Temuco, Chile), Comisión Nacional de Investigación Científica y Tecnológica (CONICYT) scholarship (21110939), Fondo Nacional de Desarrollo Científico y Tecnológico (FONDECYT) (Project 11140608), FONDECYT (Project 1141245), FONDECYT (Project 3180569) and Proyectos Basales y Vicerrectoría de Investigación, Desarrollo e Innovación (Universidad de Santiago de Chile) for financial support.

\section{Resumen}

M. Chacón-Fuentes, A. Mutis, L. Bardehle, I. Seguel, A. Urzúa, y A. Quiroz. 2019. Disminución de la actividad enzimática de la Flavonol Sintasa debido al proceso de domesticación en Ugni molinae Turcz. Cien. Inv. Agr. 46(1): 30-39. La biosíntesis de flavonoides puede verse afectada por la domesticación vegetal, reduciéndose la producción en relación al grado de domesticación. En este contexto, ha sido identificado el kaempferol (3,4', 5,7-tetrahidroxiflavona) en hojas de Ugni molinae silvestre y cultivada. La ruta biosintética del kaempferol comienza con naringenina (4', 5,7-trihidroxiflavanona), que se convierte en dihidrokaempferol (3,4', 5,7-tetrahidroxiflavanona), catalizada por la flavanona 3ß-hidroxilasa (FHT). Finalmente, se convierte en kaempferol por una enzima bifuncional llamada flavonol sintasa (FLS). Por lo tanto, nuestro estudio tiene como objetivo evaluar cómo se ve afectada la actividad de FLS en plantas de murtilla que están sujetas a un proceso de domesticación. El kaempferol fue cuantificado a partir de los extractos metanólicos de hojas recogidas en plantas cultivadas y silvestres de $U$. molinae mediante cromatografía líquida de alta resolución. Además, se realizó una extracción de enzimas para determinar la actividad de FLS. Los resultados mostraron que la concentración de kaempferol en las áreas de muestreo silvestre de Soloyo $\left(0.14 \mu \mathrm{g} \mathrm{g}^{-1}\right)$, Mehuín $\left(0.18 \mu \mathrm{g} \mathrm{g}^{-1}\right)$ y Queule $\left(0.25 \mu \mathrm{g} \mathrm{g}^{-1}\right)$ fue mayor que en sus contrapartes cultivadas. Estos datos fueron consistentes con la actividad de FLS determinada en muestras obtenidas de Manzanal Alto (134,79 pKatal), Soloyo (96,48 pKatal) y Mehuín (119,97 pKatal). Estos también exhibieron una mayor actividad enzimática que sus contrapartes cultivadas. Por lo tanto, nuestros datos sugieren que la actividad de FLS se ve reducida por la domesticación vegetal.

Palabras clave: Actividad enzimática, cultivada, Kaempferol, naringenina, silvestre. 


\section{References}

Bautista, A., F. Parra, and F. Espinoza-Garcia. 2012. Efectos de la domesticación de plantas en la diversidad fitoquímica. 253-267. En: J.C. Rojas y E.A. Malo (Eds.). Temas selectos en Ecología Química de Insectos. El Colegio de la Frontera Sur. México. 446 p.

Chacón-Fuentes, M., L. Parra, C. Rodriguez-Saona, I. Seguel, R. Ceballos, and A. Quiroz. 2015. Domestication in murtilla (Ugni molinae) reduced defensive flavonol levels but increased resistance against a native herbivorous insect. Environmental Entomology 44:627-637.

Chacón-Fuentes, M., M. Lizama, L. Parra, I. Seguel, and A. Quiroz. 2016. Insect diversity, community composition and damage index on wild and cultivated murtilla. Ciencia e Investigación Agraria 43:57-67.

Chacón-Fuentes, M., L. Parra, M. Lizama, I. Seguel, A. Urzúa, and A. Quiroz. 2017. Plant flavonoid content modified by domestication. Environmental Entomology 46:1080-1089.

Dixit, G., A. Praveen, T. Tripathi, V. Yadav, and P. Verma. 2017. Herbivore-responsive cotton phenolics and their impact on insect performance and biochemistry. Journal of Asia Pacific Entomology 20:341-351.

Fang, F., K. Tank, and W. Huang. 2013. Changes of flavonol synthase and flavonol contents during grape berry development. European Food Research Technology 237:529-540.

Flores, G., F. Moreno, G. Blanch, and M. Del Castillo. 2014. Phenylalanine ammonia-lyase, flavanone 3B-hydroxylase and flavonol synthase enzyme activity by a new in vitro assay method in berry fruits. Food Chemistry 153:130-133.

Halbwirth, H., I. Waldner, S. Miosic, M. Ibanez, G. Costa, and K. Stich. 2009. Measuring flavonoid enzyme activities in tissues of fruits species. Journal of agricultural and Food Chemistry 57:4983-4987.

Hoffmann, A. 2005. Flora Silvestre de Chile. Zona Araucana. Quinta edición. Fundación Claudio Gay. Santiago, Chile. 258 p.

Kumar, A., R. Ilavarasan, T. Jayachandran, M. Decaraman, P. Aravindhan, N. Padmanabhan, and
M. Krishna. 2009. Phytochemicals investigation on a tropical plant, Syzygium cumini from Kattuppalayam, Erode District, Tamil Nadu, South India. PJN 8:83-85.

León-Chan, R., M. López-Meyer, T. Osuna-Enciso, J. Sánudo-Barajas, J. Heredia, and J. León-Félix. 2017. Low temperature and ultraviolet-B radiation affect chlorophyll content and induce the accumulation of UV-B-absorbing and antioxidant compounds in bell pepper (Capsicum annuum) plants. Environmental and Experimental Botany 139:143-151.

Li, X., Y. Kim, Y. Kim, S. Zhao, H. Kim, E. Chung, J. Lee, and S. Park. 2013. Differential stressresponse expression of two flavonol synthase genes and accumulation of flavonols in tartary buckwheat. Journal of Plant Physiology 170:1630-1636.

Lukacin, R., I. Groning, E. Schiltz, L. Britsch, and U. Matern. 2000. Purification of Recombinant Flavanone 3 -Hydroxylase from Petunia hybrida and Assignment of the Primary Site of Proteolytic Degradation. Archives of Biochemical and Biophysics 375:364-370.

Lukacin, R., F. Wellmann, L. Britsch, S. Martens, and U. Matern. 2003. Flavonol synthase from Citrus unshiu is a bifunctional dioxygenase. Phytochemistry 62:287-292.

McKey, D., M. Elias, B. Pujol,and A. Duputtié. 2009. The evolutionary ecology of clonally propagated domesticated plants. New Phytologist 186:318332.

Meyer, R., A. DuVal, and H. Jensen. 2012. Patterns and processes in crop domestication: An historical review and quantitative analysis of 203 global food crops. New Phytologist 196:29-48.

Mikulic-Petkovsek, M., A. Slatnar, F. Stampar,and R. Veberic. 2012. HPLC-MSn identification and quantification of flavonol glycosides in 28 wild and cultivated berry species. Food Chemistry 135:2138-2146.

Nenaah, G. 2013. Potential of using flavonoids, latex and extract from Calotropis procera (Ait.) as grain protectants against two coleopteran pests of stored rice. Industrial Crops and Products 45:327-334. 
Nguyen, N., J. Kim, J. Kwon, C. Jeong, W. Lee, D. Lee, S. Hong,and H. Lee. 2016. Characterization of Arabidopsis thaliana Flavonol synthase 1 (FLS1) overexpression plants in response to abiotic stress. Plant Physiologyand Biochemistry 103:133-142.

Onyilagha, J., H. Gruber, R. Hallet, J. Holowachuk, A. Buckner, and J.Soroka. 2012. Constitutive flavonoids deter flea beetle insect feeding in Camelina sativa $\mathrm{L}$. Biochemical Systematics and Ecology 42:128-133.

Peña-Cerda, M., J. Arancibia-Radich, P.ValenzuelaBustamante, R. Perez-Arancibia, A. Barriga, I. Seguel, L. Garcia, and C. Delporte. 2017. Phenolic composition and antioxidant capacity of Ugni molinae Turcz leaves of different genotypes. Food Chemistry 217:219-227.

Preub, A., R. Stracke, B. Weisshaar, A. Hillebrecht, U. Matern, and S. Martens. 2009. Arabidopsis thaliana expresses a second functional flavonol synthase. FEBS L 583:1981-1986.

Ross-Ibarra, J., P. Morrell, and B. Gaut. 2007. Plant domestication, a unique opportunity to identify the genetic basis of adaptation. PNAS 104:8641-8648.

Ruiz, A., I. Hermosín-Gutiérrez, C. Mardones, C. Vergara, E. Herlitz, and M. Vega. 2010. Polyphenols and antioxidant activity of calafate (Berberis microphylla) fruits and other native berries from Southern Chile. Journal of Agriculture and Food Chemistry 58:6081-6089.

Scheuermann, E., I. Seguel, A. Montenegro, R. Bustos, E. Hormazábal, and A. Quiroz. 2008. Evolution of aroma compounds of murtilla fruits (Ugni molinae Turcz) during storage. Journal of Science and Food Agriculture 88:485-492.
Seguel, I., E. Peñaloza, and N. Gaete. 2000. Colecta y caracterización molecular de germoplasma de murta (Ugni molinae Turcz.) en Chile. Agro Sur 28:32-41.

Selin-Rani, S., S. Senthil-Nathan, A. Thanigaivel, P. Vasantha-Srinivasan, E. Edwin, A. Ponsankar, J. Lija-Escaline, K. Kalaivani, A. Abdel-Megeed, W. Hunter,and R. Alessandro. 2016. Toxicity and physiological effect of quercetin on generalist herbivore, Spodoptera litura Fab. and a non-target earthworm Eisenia fetida Savigny. Chemosphere 165:257-267.

Simirgiotis, M., J. Bórquez, and G. SchmedaHirschmann. 2009. Antioxidant capacity, polyphenolic content and tandem HPLC-DAD-ESI/ MS profiling of phenolic compounds from the South American berries Luma apiculata and $L$. Chequén. Food Chemistry. 139:289-299.

Valdebenito, G., J. Campos, O. Larraín, M. Aguilera, C. Kahler, M. Ferrando, E. García, and A. Sotomayor. 2003. Ugni molinae Turcz, murta, murtilla, uni, Murtilla. Boletín divulgativo No. 3. Proyecto FONDEFINFOR- Fundación Chile. Santiago, Chile. 6 p.

Vazhappilly, C., D. Graham, and R. Vasantha. 2017. Plant flavonoids in cancer chemoprevention: role in genome stability. The Journal of Nutritional Biochemistry 45:1-14.

Xu, F., L. Linling, Z. Weiwei, C. Hua, S. Nannan, C. Shuiyuan, and W. Yan. 2012. Isolation, characterization, and function analysis of a flavonol synthase gene from Ginkgo biloba. Molecular Biology Reports 39:2285-2296.

Yang, L., T. Li, F. Li, J. Lemcoff, and S. Cohen. 2008. Fertilization regulates soil enzymatic activity and fertility dynamics in a cucumber field. Scientia Horticulturae 116:21-26.

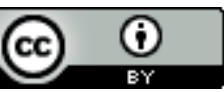

This work is licensed under a Creative Commons Attribution 4.0 International License. 